\title{
Celebrating DAVID MCLAUCHLAN'S CONTRIBUTION
}

The Victoria University of Wellington Law Review is proud to publish this special issue to mark David McLauchlan's 40th anniversary as a faculty member.

David has had an extraordinary career as one of the Commonwealth's leading writers on contract law, and in his earlier days on wider issues of commercial law. His contribution to scholarship, as shown by his bibliography, has been enormous. But, we would suggest, his contribution to the teaching of generations of students at Victoria has been greater still. Over the course of the last 40 years David has enthused countless students and given them the valuable gift of his particular way of looking at cases and the way that judges interpret both the law and commercial contracts. His focus has always been on teaching undergraduates "how to think", rather than imparting a particular body of knowledge. He has encouraged, cajoled, and sometimes blustered students into developing their own critical insights that they can carry forward into their own careers. In doing so David has never been shy of sharing his own enthusiasm for the research that he has conducted into what others might have considered to be dry areas of commercial contract law, and his classes have been infinitely richer as a result. Many students would be able to recount the severity, but also the good humour, with which David has led them to the error of their ways. It has always been to David's credit, and the amazement of his colleagues, that some of the students most exposed by this process are those who come to hold David in the greatest affection, not just because they survived his class, but because he taught them something difficult. It is not by accident that his wall is festooned with teaching awards.

As a colleague, David has never left his colleagues doubting his commitment to undergraduate teaching, and his belief in the importance of the vitality of the classroom experience for students. He believes that both teaching and scholarship are inextricably linked, and his many contributions to faculty meetings reflect that. As many colleagues would attest David has always been insistent on giving space to younger faculty members to grow or develop their careers, and his long service as chair of the Faculty's Leave Committee is testament to this. The colleague experience of Victoria, like the experience of our students, would be much the lesser without David.

In conceiving of this issue we invited contributions from those who represented different aspects of David's career. We were delighted with those who accepted. We are particularly delighted that the issue contains so much written by those who have been personally involved with David either as a student, a colleague, or a friend. We are particularly proud that this issue starts, as any issue in David's honour should start, with an article by two of his recent students, Amelia Keene and Sarah Leslie, followed immediately by an article by Justice Kós, one of David's former students and a former colleague in chambers. David's current colleagues are then represented by a contribution by 
Professor Susy Frankel who taught for many years with David in his contract course, while David's overseas colleagues are Professors Tolhurst, Carter and Peden from Sydney where he spent a very successful period teaching in the Masters programme. The community of New Zealand contract scholars are represented by Professors John Burrows and Rick Bigwood. David's collaborators are represented by Professor Charles Rickett and Francis Dawson. The last contribution is by Professor Francesco Schurr of Liechtenstein who along with his wife Professor Verena Murschetz have visited Victoria for the best part of a decade from their base in Innsbruck, and whom David and his wife have visited in return.

Geoff McLay

Law Commissioner and former Managing Editor of the VUWLR

Dr Nessa Lynch

Managing Editor of the VUWLR 